\title{
Kajian Penambahan Gambir sebagai Bahan Penyamak Nabati terhadap Mutu Kimiawi Kulit Kambing
}

\section{Study of Gambier Addition as Vegetable Tanner Materials to Chemical Quality Goat Leather}

\author{
I. Juliyarsi, D. Novia dan J. Helson \\ Fakultas Peternakan Universitas Andalas \\ email: deni_novia@yahoo.co.id
}

(Diterima: 27 Oktober 2012; Disetujui: 3 Januari 2013)

\begin{abstract}
Gambier contains tannin which functions as vegetable tanning material. This study aimed to determine, the gambier addition to produces the best chemical quality leather according to Indonesian National Standard chemical quality goatleather (SNI 06-0463-1989). The method was used experimental method randomized block design, which consists of 5 treatments with 4 replications. Treatment of this study was added the gambier percentage (\%), each treatment consisting of: treatment A: 15\%, B: 20\%, C: 25\%, D: $30 \%$, and E: $35 \%$. The variables were measured water content, oil/fat content, water-soluble substances content, levels of substances rawhide, levels of insoluble ash in the water, levels of tanning substances (tannins) bound and the tanning degree. The results showed a significantly different effect $(P<0.05)$ to decrease water content, levels of substances rawhide, levels of substances soluble in water and increasing tanning degree and did not differ significantly $(P>0.05)$ oil/fat content, ash content and levels of tanning substances (tannins) bound. The conclusion of this study was the addition of $25 \%$ was the best gambier percentage, with $17.06 \pm 0.15 \%$ water content, the fat/oil $7.69 \pm 1.24 \%$, the levels of water-soluble substances $4.16 \pm 0.99 \%$, levels of substances rawhide $42.47 \pm 6.39 \%, 0.99 \pm 0.03 \%$ levels of insoluble ash in the water, levels of tanning substances (tannins) bound $27.63 \pm 2.75 \%$ and $65.46 \%$ tanning degree, which all meet the quality standard ISO test 06-0994-1989 and SNI No.0253-2009.
\end{abstract}

Keywords: gambier, vegetable tanning, tannins, chemical quality, goat leather.

\section{PENDAHULUAN}

Penyamakan merupakan proses mengubah kulit mentah menjadi kulit samak yang stabil, tidak mudah membusuk. Prinsip penyamakan adalah memasukkan bahan penyamak ke dalam jaringan kulit yang berupa jaringan kolagen sehingga terbentuk ikatan kimia antara keduanya, dan didapatkan kulit yang lebih tahan terhadap faktor perusak, seperti mikroorganisme, kimia dan fisik, sehingga dapat diolah menjadi produk. Kulit kambing merupakan salah satu jenis kulit yang sesuai untuk dijadikan kulit tersamak karena ketersediaan ternak kambing di Sumatera Barat cukup tinggi. Kulit kambing ini terdiri dari tiga lapisan pokok yaitu epidermis, dermis dan hypodermis, di mana ketiga lapisan ini secara kimiawi mudah rusak akibat aktifitas mikroorganisme patogen jika tidak dilakukan penanganan yang baik. Upaya untuk menjadikan kulit kambing sebagai salah satu hasil ikutan yang tidak mudah rusak dan dapat meningkatkan nilai ekonomis adalah dengan melakukan penyamakan kulit.

Industri penyamakan kulit biasanya menggunakan bahan penyamak sintetis dan nabati. Bahan penyamak sintetis biasanya menggunakan proses chrome taning menghasilkan limbah cair yang mengandung krom. Krom yang dihasilkan adalah krom yang bervalensi $3+$ (trivalen) yang diperoleh dari penyamakan krom. Limbah cair yang mengandung krom ini dapat membahayakan lingkungan karena krom trivalen dapat berubah menjadi krom heksavalen pada kondisi basa yang merupakan jenis limbah B3 yang dapat membahayakan bagi kesehatan.

Penyamakan secara nabati menggunakan kayu akasia dan bakau juga dapat berdampak buruk bagi kelestarian lingkungan. Kedua jenis pohon ini termasuk yang dilindungi bagi 
kelestarian lingkungan. Pengambilan kulit kayu yang dilakukan secara terus menerus dapat mengakibatkan gangguan pertumbuhan pada pohon bahkan bisa membuat pohon menjadi mati, maka perlu dicari pengganti bahan penyamak yang ramah lingkungan untuk menggantikan bahan penyamak krom akasia dan bakau tersebut. Salah satu alternatif bahan penyamak tersebut adalah dengan menggunakan gambir. Penggunaan gambir sebagai bahan penyamak memiliki berbagai keuntungan yaitu gambir sudah dibudidayakan sehingga selalu tersedia sebagai bahan penyamak kulit tanpa mengganggu kelestarian lingkungan hidup.

Ketersediaan gambir cukup banyak, hal ini terlihat dari luas tanaman gambir Sumatera Barat \pm 19.575 ha dengan total produksi 13.956 ton yang terpusat pada Kabupaten 50 kota dan Kabupaten Pesisir Selatan. Sekitar $80 \%$ pasar ekspor komoditi gambir dunia berasal dari Indonesia dan $80 \%$ ekspor gambir dari Indonesia dipasok oleh Provinsi Sumatera Barat (Data Badan Pusat Statistik Provinsi Sumatera Barat, 2009).

Unit Pelaksana Teknis Dinas Industri Pengolahan Kulit Padang Panjang yang merupakan industri penyamakan kulit milik pemerintah satu-satunya di Pulau Sumatera, menggunakan bahan penyamak sintetis dan nabati dengan menggunakan ekstrak mimosa. Aplikasi bahan penyamak nabati menggunakan ekstrak mimosa pada kulit kambing dapat dilakukan dengan penambahan bahan penyamak sebanyak 20-30\% yang dimasukkan secara bertahap (Sumarni, 2005) dan ditambahkan oleh Wahyuningsih (2007) yang menyatakan bahwa penambahan $25 \%$ mimosa pada kulit kelinci samak bulu menghasilkan kualitas terbaik terhadap daya serap air dan organoleptik kulit. Pra penelitian yang dilakukan di UPTD Pengolahan Kulit Padang Panjang dengan menggunakan bahan penyamak nabati lainnya yang berasal dari gambir sebanyak 15$35 \%$ diperoleh kulit samak yang cukup baik dengan warna kuning kecoklatan, namun penulis belum dapat menentukan persentase penambahan yang tepat untuk menghasilkan mutu kimiawi kulit kambing tersamak dengan hasil terbaik. Penelitian ini bertujuan untuk mengetahui pemberian gambir pada level berapa yang akan menghasilkan kulit tersamak dengan mutu kimiawi yang terbaik dan sesuai dengan Standar Nasional Indonesia mutu kimiawi kulit kambing (SNI, 1989).

\section{MATERI DAN METODA}

\section{Materi Penelitian}

Bahan baku yang digunakan adalah: 20 lembar kulit kambing yang diperoleh dari peternak Kambing Kacang di Kec. Pauh Kota Padang, bahan penyamak gambir dari kota Payakumbuh sebanyak $25 \%( \pm 8 \mathrm{~kg})$ yang dihitung dari penimbangan berat bloten kulit. Bahan kimia diperoleh di Unit Pelaksana Kerja Teknis (UPTD) Pengolahan Kulit Kota Padang Panjang antara lain: $\mathrm{H}_{2} \mathrm{SO}_{4}$ (asam sulfat pekat) $1,5 \%, \mathrm{NaCl}$ (garam) $10 \%$, natrium format $0,5 \%, \mathrm{Za}$ (pupuk) $0,5 \%$, teepol $1 \%$, oropon $0,5 \%$, FA (asam semut) $1 \%, \mathrm{Na}_{2} \mathrm{~S} 2 \%$, natrium bikarbonat (soda kue/ $\mathrm{NaHCO}_{3}$ ) 2,5\%, sodium karbonat $\left(\mathrm{Na}_{2} \mathrm{CO}_{3}\right) 0,5 \%, \mathrm{Ca}(\mathrm{OH})_{2}$ (kapur tohor) 6\%, anti jamur (preventol) $0,02 \%$, dan $\mathrm{H}_{2} \mathrm{O}$ (air) $1.280 \%$. Persentase diambil dari berat kulit. Sedangkan bahan kimia lain yang digunakan dalam pengujian mutu kimiawi kulit tersamak adalah : petroleum ether, air suling, natrium sulfat, asam sulfat pekat, cupri sulfat $\left(\mathrm{CuSO}_{4} 5 \mathrm{H}_{2} \mathrm{O}\right)$, indikator methyl biru, larutan natrium hidroksida $(\mathrm{NaOH})$, dan natrium hidroksida. Peralatan yang digunakan adalah: tanning drum, timbangan analitik, stop watch, cawan porselen, blender, pisau, gunting, oven, desikator, labu Koch, pipet, cawan gelas, baskom, water bath dan labu Kjeldahl.

\section{Metode Penelitian}

Metode yang digunakan dalam penelitian ini adalah metode eksperimen dengan menggunakan rancangan acak kelompok yang terdiri dari 5 perlakuan dengan 4 ulangan, di mana kelompok sebagai ulangan. Perlakuan tersebut adalah pemberian gambir berdasarkan berat Bloten : A (15\% gambir), B (20\% gambir), C (25\% gambir), D (30\% gambir) dan $\mathrm{E}$ (35\% gambir). 


\section{Tempat Pengambilan Contoh Uji (SNI 06- 0463-1989)}

Tempat pengambilan contoh uji dapat dilihat pada Gambar 1.

\section{Pengamatan Mutu Kimiawi Kulit Tersamak}

Kulit hasil penyamakan dilakukan pengamatan secara kimia, berdasarkan SNI.060463-1989 yaitu Derajat Penyamakan (DP) kulit tersamak dengan parameter uji meliputi: kadar air, kadar minyak /lemak, kadar zat larut dalam air, kadar abu tak larut, kadar zat kulit mentah, kadar zat penyamak (tanin) terikat dan derajat penyamakan. Untuk pengujian kimiawi, kulit dipotong-potong dengan pisau menjadi bagian kecil-kecil dengan ukuran $(5 \times 5) \mathrm{mm}^{2}$. Kemudian kulit dicampur rata (homogen). Selanjutnya digunakan sebagai contoh pengujian.

\section{Prosedur Penyamakan Nabati dengan Menggunakan Gambir}

Prosedur kerja penyamakan kulit kambing dilakukan berdasarkan metode modifikasi dari prosedur penyamakan kulit Balai Besar Kulit Karet dan Plastik Yogyakarta (2010), persentase bahan yang digunakan adalah dari berat kulit setelah ditimbang untuk proses soaking dan liming, sedangkan persentase yang digunakan untuk proses selanjutnya adalah dari berat bloten kulit.

Prosedur kerja yang dilakukan pada penelitian ini adalah sebagai berikut:

1. Perendaman (soaking)

Dimasukkan kedalam drum pemutar $600 \% \mathrm{H}_{2} \mathrm{O}$, lalu ditambahkan $0,5 \%$ teepol, ditambahkan $0,5 \% \mathrm{Na}_{2} \mathrm{CO}_{3}$, ditambahkan $0,01 \%$ anti jamur (preventol), diputar selama 60 menit, kemudian dicuci dengan air mengalir.

2. Pengapuran (liming)

Dimasukkan 200\% $\quad \mathrm{H}_{2} \mathrm{O}, \quad$ lalu ditambahkan $2 \% \mathrm{Na}_{2} \mathrm{~S}(\mathrm{SN})$ ditambahkan $2 \%$ kapur tohor kemudian putar 30 menit. Selanjutnya didiamkan 30 menit. Setelah itu, ditambahkan kapur $2 \%, \quad 2 \% \quad \mathrm{Na}_{2} \mathrm{~S} \quad(\mathrm{SN})$ kemudian diputar selama 30 menit. Setelah 30 menit, ditambahkan lagi kapur $2 \%$, diputar 30 menit, dicek $\mathrm{pH}=12$ dan overnight .

3. Pembuangan daging (fleshing) dengan menggunakan pisau

4. Penimbangan untuk mencari bloten (berat setelah bulu hilang)

5. Pembuangan kapur (deliming)

- $200 \% \mathrm{H}_{2} \mathrm{O}$, ditambah $0,5 \%$ pupuk $\mathrm{Za}$, kemudian diputar 30 menit

- Ditambahkan $\mathrm{Fa} / \mathrm{H}_{2} \mathrm{SO}_{4}$, kemudian diputar 30 menit

- Cek pH 7-8, kemudian diputar 60 menit.

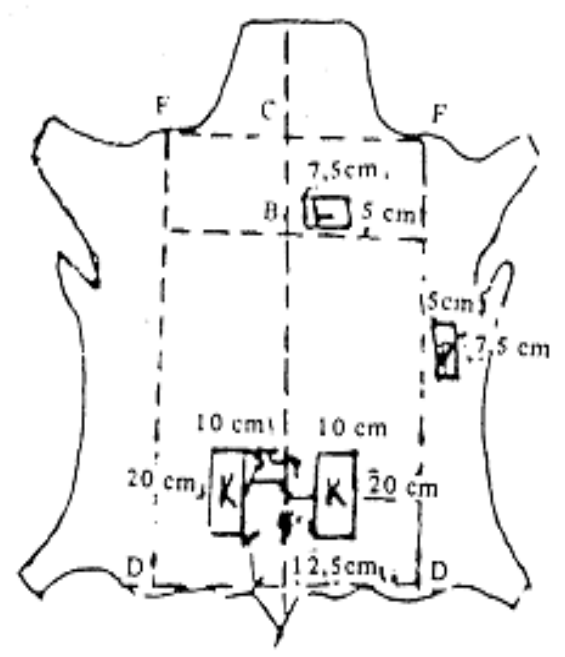

Gambar 1. Tempat Pengambilan Contoh Uji. K = Krupon $(20 \times 10) \mathrm{cm}^{2}$, $\mathrm{P}=$ Perut $(7.5 \times 5) \mathrm{cm}^{2}, \mathrm{~L}=\operatorname{Leher}(7.5 \times 5) \mathrm{cm}^{2}$ 
6. Pengikisan protein (beating), degresing, (penyabunan lunak)

- $0.5 \%$ teepol, ditambah $0.5 \%$ oropon kemudian diputar selama 30 menit

- Dicuci sampai bersih

7. Pengasaman (pickle)

- $80 \% \mathrm{H}_{2} \mathrm{O}$, ditambahkan 10-15\% $\mathrm{NaCl}$ (garam), kemudian diputar selama 10 menit

- Ditambahkan 0,5 \% formid acid dilarutkan 1:10, kemudian diputar selama 30 menit

- Ditambahkan 1-1,5\% $\mathrm{H}_{2} \mathrm{SO}_{4}$, larutkan 1:10, kemudian dibagi 3 lalu dimasukkan $\mathrm{H}_{2} \mathrm{SO}_{4}(1,2,3)$ x 30 menit per larutan, kemudian diputar kembali selama 60 menit

- Dimasukkan 0,01 \% anti jamur, kemudian diputar 10 menit, ukur $\mathrm{pH}$, $\mathrm{pH}=4-5$

8. Penyamakan dengan gambir

- $100 \% \mathrm{H}_{2} \mathrm{O}$, lalu ditambahkan gambir pada masing-masing perlakuan sebagai berikut :

- Perlakuan I = $15 \%$ gambir dibagi 3 bagian, gambir pertama diputar 30 menit, dimasukkan lagi lalu putar 30 menit sampai gambir yang ke 3

- Perlakuan II $=20 \%$ gambir dibagi 4 bagian, gambir pertama diputar 30 menit, dimasukkan lagi lalu putar 30 menit sampai gambir yang ke 4

- Perlakuan III $=25 \%$ gambir dibagi 5 bagian, gambir pertama diputar 30 menit, dimasukkan lagi lalu putar 30 menit sampai gambir yang ke 5

- Perlakuan IV $=30 \%$ gambir dibagi 6 bagian, gambir pertama diputar 30 menit, dimasukkan lagi lalu putar 30 menit sampai gambir yang ke 6

- Perlakuan V $=35 \%$ gambir dibagi 7 bagian, gambir pertama diputar 30 menit, dimasukkan lagi lalu diputar 30 menit sampai gambir yang ke 7 .

9. Netralisir

- $100 \% \mathrm{H}_{2} \mathrm{O}$, ditambah $1 \% \mathrm{NaHCO}_{3}$ larutkan 1:10 dibagi 2

- Dimasukkan larutan (1.2) x 30 menit per larutan. Pengecekan $\mathrm{pH}=5$

10. Pencucian

\section{HASIL DAN PEMBAHASAN}

\section{Kadar Air}

Rataan kadar air kulit kambing samak dengan gambir, terendah terdapat pada perlakuan $\mathrm{E}$ dengan rataan $16,00 \%$ dan tertinggi terdapat pada perlakuan A dengan rataan 17,76\% (Tabel 1). Hasil analisis keragaman menunjukkan bahwa perlakuan penambahan gambir memberikan pengaruh terhadap kadar air penyamakan dengan gambir pada kulit kambing.

Hasil uji jarak berganda Duncan's menunjukkan, bahwa rataan kadar air penyamakan dengan gambir pada perlakuan A memberikan pengaruh tidak nyata dengan perlakuan $\mathrm{B}$ dan $\mathrm{C}$ dan berbeda nyata dengan perlakuan D dan E, sedangkan perlakuan D berbeda nyata dengan perlakuan E. Tingginya kadar air pada perlakuan A dipengaruhi oleh persentase pemberian gambir yang ditambahkan pada perlakuan tersebut di mana tannin pada gambir belum terpenetrasi dengan baik untuk melakukan ikatan dengan serat-serat kolagen pada kulit kambing, menyebabkan rendahnya daya ikat kolagen dengan tanin sehingga memungkinkan air bebas pada kulit masih tinggi. Hal ini sesuai dengan pendapat Ibrahim dkk. (2005) bahwa zat penyamak yang menembus permukaan kulit (rajah) dan dari bagian dagingnya kedalam struktur anyaman serat hingga air bebas pada kulit akan keluar.

Rendahnya kadar air pada perlakuan E (16\%) sejalan dengan peningkatan konsentrasi gambir yang ditambahkan dalam perlakuan tersebut, sehingga meningkatkan kesempatan tanin yang terdapat pada gambir untuk berpe netrasi dan berikatan dengan serat-serat 
Tabel 1. Nilai Rataan Kadar Air, Minyak/Lemak, Zat Larut dalam Air Hasil Penelitian (\%)

\begin{tabular}{cccc}
\hline Perlakuan & \multicolumn{1}{c}{ K. Air } & \multicolumn{1}{c}{ K. Minyak /Lemak } & K. Zat Larut dalam Air \\
\hline A & $17,76 \pm 0,32^{\mathrm{a}}$ & $7,30 \pm 1,33$ & $7,87 \pm 0,91^{\mathrm{a}}$ \\
B & $17,35 \pm 0,63^{\mathrm{ab}}$ & $7,98 \pm 1,80$ & $6,44 \pm 2.20^{\mathrm{b}}$ \\
C & $17,06 \pm 0,15^{\mathrm{ab}}$ & $7,69 \pm 1,24$ & $4,16 \pm 0,99^{\mathrm{c}}$ \\
D & $16,91 \pm 0,43^{\mathrm{b}}$ & $8,48 \pm 1,75$ & $4,23 \pm 0,88^{\mathrm{c}}$ \\
E & $16,00 \pm 0,58^{\mathrm{c}}$ & $8,41 \pm 0,77$ & $4,14 \pm 0,96^{\mathrm{c}}$
\end{tabular}

Keterangan : Rataan dengan superskrip huruf yang berbeda menunjukkan pengaruh yang berbeda nyata $(\mathrm{P}<0.05), \mathrm{A}=$ penambahan gambir $15 \%, \mathrm{~B}=20 \%, \mathrm{C}=25 \%, \mathrm{D}=30 \%$ dan $\mathrm{E}=35 \%$

kolagen kulit dan memperkecil kesempatan air untuk berikatan dengan kulit kambing. Novia (2009) menyatakan, nilai kadar air kulit juga dipengaruhi oleh sifat penetrasi (daya tembus) bahan penyamak ke dalam kulit, di mana kandungan zat penyamak (tanin) mulai berdifusi (menyebar) ke dalam kulit dan merekatkan diri pada serat-serat serta pada waktu yang sama melepaskan sejumlah air.

Kadar air sangat erat kaitannya dengan kadar lemak/minyak yang terdapat pada kulit samak, di mana semakin tinggi kadar lemak/minyak pada kulit dapat menurunkan kadar air pada kulit karena senyawa-senyawa asam yang terdapat pada lemak /minyak mempunyai kemampuan dalam melepaskan ikatan hidrogen kulit sehingga dapat menurunkan kadar air dalam kulit. Sesuai dengan pendapat Nurwanto dan Djariah (1997), bahwa kadar air suatu bahan berbanding terbalik dengan kadar lemak/minyak dimana semakin menurun kadar lemak/minyak maka kadar air semakin tinggi, hal ini disebabkan karena senyawa asam akan melepas ikatan hidrogen air yang terdapat di dalam kulit.

Pada penelitian sebelumnya, penyamakan nabati menggunakan gambir pada konsentrasi $4 \%$ pada kulit kambing diperoleh ratarata kadar air $16,99 \%$ dan penyamakan nabati dengan menggunakan limbah gambir pada konsentrasi $4 \%$ pada kulit kambing diperoleh rata-rata kadar air 18\% (Gustriyeni et al., 2009). Hasil penelitian penyamakan dengan gambir pada kulit kambing dengan hasil penelitian sebelumnya memenuhi syarat BSN (2009) dimana batas maksimum kadar air menurut SNI adalah $18 \%$.

\section{Kadar Minyak/Lemak}

Dari Tabel 1 terlihat bahwa rataan kadar minyak penyamakan nabati dengan gambir pada kulit kambing berada pada kisaran 7,30\%$8,40 \%$. Hasil analisis keragaman menunjukkan bahwa perlakuan tidak berpengaruh terhadap kadar minyak penyamakan nabati dengan gambir pada kulit kambing. Berbeda tidak nyatanya kadar minyak/lemak pada kulit samak disebabkan oleh perlakuan yang sama dalam proses pembuangan lemak (degreasing) sebelum melakukan proses penyamakan. Fahidin (1977) dalam Nugraha (1999) menyatakan pembuangan lemak yang sempurna akan membantu dalam proses penetrasi bahan penyamak ke dalam kulit lebih lancar dan tidak terhambat oleh gumpalan-gumpalan lemak pada kulit. Ibrahim dkk. (2005) menambahkan, pada pembuangan lemak digunakan bahan pembantu seperti Teepol, baymol A dan lainlain yang berfungsi untuk mengemulsikan lemak sehingga mudah untuk dilarutkan.

Pada penelitian sebelumnya penyamakan nabati menggunakan gambir pada konsentrasi $4 \%$ pada kulit kambing diperoleh ratarata kadar lemak/minyak $1,10 \%$ dan penyamakan nabati menggunakan limbah gambir pada konsentrasi $4 \%$ pada kulit kambing diperoleh rata-rata kadar lemak/minyak $0,72 \%$ (Gustriyeni, dkk. 2009). Hasil penyamakan nabati menggunakan kulit kayu akasia dengan konsentrasi $18 \%$ diperoleh rata-rata kadar lemak / minyak 3,51\% (Nugraha, 1999). Tingginya kadar lemak/minyak penyamakan nabati gambir pada kulit kambing karena di dalam gambir terdapat Fixed oil yang merupakan minyak yang sukar manguap dan zat lilin yang 
juga merupakan monoester dari asam lemak dan alkohol. Sesuai dengan pendapat Thorpe dan Whiteley (1921) dalam Novia (2009) menyatakan, Fixed oil merupakan minyak yang sukar manguap yang dimiliki oleh gambir. Pada tanaman gambir juga terdapat zat lilin yang terletak pada lapisan permukaan daun gambir yang merupakan monoester dari suatu asam lemak dan alkohol yang dimiliki oleh gambir. Pada perlakuan D dan E tidak memenuhi syarat mutu SNI. 0253:2009 sedangkan perlakuan $\mathrm{A}, \mathrm{B}$, dan $\mathrm{C}$ memenuhi syarat mutu SNI. 0253:2009 dimana batas persentase kadar lemak/minyak maksimum adalah $8 \%$.

\section{Kadar Zat Larut Dalam Air}

Rataan kadar zat larut dalam air penyamakan dengan gambir pada kulit kambing tertinggi terdapat pada perlakuan A $(7,87 \%)$ dan terendah adalah pada perlakuan E $(4,14 \%)$ (Tabel 1). Hasil analisis keragaman menunjukkan bahwa perlakuan memberikan pengaruh terhadap kadar zat larut dalam air penyamakan dengan menggunakan gambir pada kulit kambing. Hasil uji jarak berganda Duncan's menunjukkan, bahwa rataan kadar zat larut dalam air penyamakan nabati dengan gambir pada perlakuan A berbeda tidak nyata terhadap perlakuan B dan berbeda nyata dengan C, D dan E. Tingginya kadar zat larut dalam air pada perlakuan A dipengaruhi oleh persentase pemberian gambir yang ditambahkan dalam penyamakan kulit dimana tanin belum melakukan penetrasi dengan baik untuk membentuk ikatan dengan serat-serat kolagen pada kulit kambing sehingga beberapa kandungan tanin pada gambir tidak berikatan dengan kulit dan larut ke dalam air begitu juga dengan perlakuan B. Menurut Ibrahim dkk. (2005) pemberian konsentrasi bahan penyamak yang lebih rendah akan menyebabkan reaksi atau ikatan bahan penyamak nabati dengan protein kulit akan lebih rendah.

Kadar zat larut dalam air terendah terdapat pada perlakuan E $(4,14 \%)$ dan berbeda tidak nyata terhadap $\mathrm{C}(4,16 \%)$ dan $\mathrm{D}(4,23 \%)$. Rendahnya kadar zat larut dalam air pada perlakuan tersebut karena bahan penyamak telah saling berikatan baik dengan kulit mau- pun antara sesama bahan bahan penyamak sehingga menghasilkan zat larut dalam air yang rendah. Berbeda tidak nyatanya perlakuan $\mathrm{E}$ $(4,14 \%)$ dengan perlakuan $\mathrm{C}(4,16 \%)$ dan $\mathrm{D}$ $(4,23 \%)$ terjadi karena pada konsentrasi tersebut tanin pada gambir telah berikatan dengan baik pada kulit kambing dan kadar zat larut dalam air semakin menurun. Menurut Purnomo (1991), selama proses penyamakan berlangsung terjadi dua tahap dalam reaksinya yaitu, tahap pertama terjadinya reaksi antara gugus hidroksil yang terdapat dalam zat penyamak nabati dengan dengan struktur kolagen, kedua diikuti oleh reaksi ikatan dari molekul zat penyamak dengan molekul zat penyamak lainnya sampai ruang kosong yang terdapat di antara rantai kolagen terisi seluruhnya. Ditambahkan oleh Ibrahim dkk. (2005) konsentrasi bahan penyamak yang tinggi di luar kulit dapat meningkatkan difusi bahan penyamak. Oleh sebab itu semakin tinggi konsentrasi bahan penyamak maka zat penyamak yang dapat masuk kedalam jaringan kulit jumlahnya semakin banyak sehingga jumlah kadar zat penyamak yang terikat oleh kolagen kulit semakin meningkat.

Pada penelitian sebelumnya penyamakan nabati menggunakan gambir pada konsentrasi $4 \%$ pada kulit kambing diperoleh ratarata kadar zat larut dalam air 3,18\% dan penyamakan nabati menggunakan limbah gambir pada konsentrasi $4 \%$ pada kulit kambing diperoleh rata-rata kadar zat larut dalam air 1,22\% (Gustriyeni, dkk. 2009). Kadar zat larut dalam air penyamakan nabati menggunakan kulit kayu akasia dengan konsentrasi 18\% diperoleh rata-rata $1,59 \%$ (Nugraha, 1999). Hasil kadar zat larut dalam air penyamakan dengan gambir pada kulit kambing pada perlakuan $\mathrm{C}, \mathrm{D}$ dan $\mathrm{E}$ memenuhi syarat SNI. 06-0463-1989, sedangkan untuk perlakuan A dan B tidak memenuhi syarat SNI. 06-04631989, di mana batas persentase kadar zat terlarut dalam air maksimum $6 \%$.

\section{Kadar Zat Kulit Mentah}

Hasil statistik kadar zat kulit mentah penyamakan nabati dengan gambir pada kulit kambing dapat dilihat pada Gambar 2. 


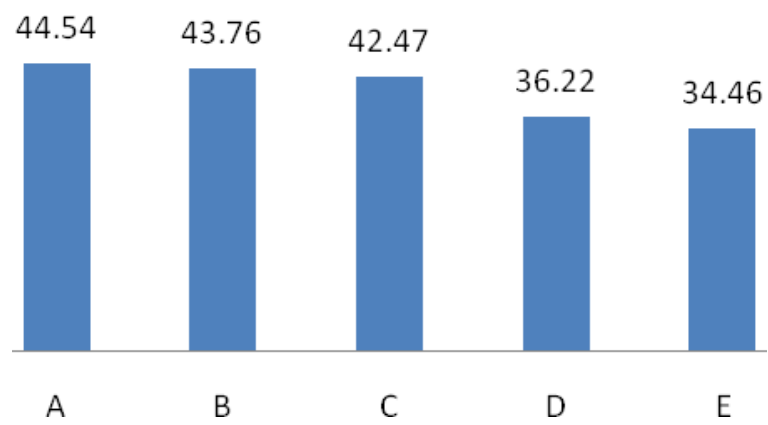

Gambar 2. Rataan Kadar Zat Kulit Mentah Hasil Penelitian (\%). A = penambahan gambir 15\%, B $=20 \%, \mathrm{C}=25 \%, \mathrm{D}=30 \%$ dan $\mathrm{E}=35 \%$

Rataan kadar zat kulit mentah penyamakan dengan gambir pada kulit kambing tertinggi terdapat pada perlakuan A, dengan rataan $44,54 \%$ dan terendah terdapat pada perlakuan E dengan rataan $34,46 \%$ (Gambar 2). Hasil analisis keragaman menunjukkan bahwa perlakuan memberikan pengaruh terhadap kadar zat kulit mentah penyamakan nabati dengan menggunakan gambir.

Hasil uji jarak berganda Duncan's menunjukkan, kadar zat kulit mentah penyamakan dengan gambir pada kulit kambing, pada perlakuan A memberikan pengaruh berbeda nyata terhadap perlakuan $\mathrm{B}, \mathrm{C}, \mathrm{D}$ dan $\mathrm{E}$. Tingginya kadar zat kulit mentah pada perlakuan A dipengaruhi oleh persentase pemberian gambir yang ditambahkan dalam penyamakan kulit sehingga mempengaruhi terhadap kemampuan gambir untuk berpenetrasi dan berikatan dengan kolagen kulit. Menurut Markmann (2009) dalam Kasim (2011), zat penyamak yang dapat bereaksi dengan serat kolagen pada bahan penyamak gambir berlangsung secara cepat, dikategorikan kepada jenis ekstrak yang spesial untuk menyamak kulit dan menyatu secara cepat dengan protein kulit.

Kadar zat kulit mentah terendah pada perlakuan $\mathrm{E}$ seiring dengan peningkatan konsentrasi gambir yang diberikan sehingga bahan penyamak yang terdapat pada gambir mempunyai kesempatan yang lebih besar untuk berikatan dengan kolagen pada kulit sehingga mengakibatkan kadar zat kulit mentah yang tidak berikatan semakin menurun, sesuai dengan pendapat Ibrahim dkk.
(2005) pemberian konsentrasi bahan penyamak yang lebih tinggi akan menyebabkan reaksi atau ikatan bahan penyamak nabati dengan protein kulit akan lebih cepat. Ditambahkan Sharphouse (1978) dalam Nugraha (1999) untuk mempercepat difusi dan penetrasi bahan penyamak yang kadar penyamaknya tinggi dapat dibantu dengan gerakan mekanis.

Prinsip dari penyamakan yaitu memasukkan bahan tertentu yang disebut bahan penyamak ke dalam anyaman atau jaringan serat kolagen sehingga terjadi ikatan kimia. Terjadinya ikatan ini ditentukan oleh struktur fisik dan kimiawi kulit yang akan disamak (perlakuan awal seperti pengapuran dan pembuangan kulit), serta bahan penyamak yang digunakan. Pada penelitian sebelumnya, penyamakan nabati menggunakan gambir pada konsentrasi $4 \%$ pada kulit kambing diperoleh rata-rata kadar zat kulit mentah $56,98 \%$ dan penyamakan nabati menggunakan limbah gambir pada konsentrasi $4 \%$ pada kulit kambing diperoleh rata-rata kadar zat kulit mentah 65,53\% (Gustriyeni, dkk. 2009). Hasil penelitian kadar zat kulit mentah kulit kambing penyamakan dengan gambir, dan penelitian sebelumnya memenuhi syarat menurut SNI. 06-0994-1989, dimana batas minimal zat kulit mentah minimal $1 \%$.

\section{Kadar Abu Tak Larut}

Rataan kadar abu tak larut dalam air penyamakan dengan gambir pada kulit kambing dengan kisaran 0,82-1,00\% (Gambar 3). Hasil analisis keragaman menunjukkan bahwa 
perlakuan tidak memberikan pengaruh terhadap kadar kadar abu tak larut penyamakan dengan gambir pada kulit kambing. Hal ini disebabkan tanin sebagai bahan penyamak tidak mengandung unsur mineral dan merupakan senyawa organik yang terdiri dari unsur C, H dan O (Howes, 1953. dalam Nugraha, 1999).

Abu tak larut adalah sisa pembakaran dari kulit tersamak setelah diambil minyak dan atau lemak serta zat larut dalam air. Dalam kadar abu tak larut terkandung unsurunsur anorganik yang tidak bisa larut dalam air (Novia, 2009). Fahidin (1977) dalam Nugraha (1999) menambahkan, kulit hewan yang belum disamak mengandung mineral sekitar $0,5 \%$ yang terdiri dari $\mathrm{K}, \mathrm{Ca}, \mathrm{Mg}, \mathrm{Fe}$, dan Na. Seperti terlihat pada data hasil pengujian kadar abu tak larut, kulit samak mengandung mineral yang jumlahnya lebih tinggi dibandingkan dengan kulit mentah. Hal ini disebabkan karena terjadinya pengikatan unsur-unsur mineral oleh protein kulit dalam proses pengapuran. Ditambahkan oleh Radiman (1990) dalam Nugraha (1999), terjadinya reaksi pengikatan unsur $\mathrm{Ca}$ dari kapur oleh protein pada proses pengapuran, apabila proses buang kapurnya tidak sempurna, maka unsur $\mathrm{Ca}$ di dalam kulit masih akan terikat.

Pada penelitian sebelumnya, penyamakan dengan gambir pada konsentrasi $4 \%$ pada kulit kambing menghasilkan rata-rata kadar abu tak larut $0,78 \%$ dan penyamakan dengan limbah gambir pada konsentrasi $4 \%$ pada kulit kambing menghasilkan rata-rata kadar abu tak larut $0,34 \%$ (Gustriyeni, dkk. 2009). Penyamakan nabati menggunakan kulit kayu akasia dengan konsentrasi $18 \%$ diperoleh rata-rata kadar abu tak larut 3,33\% (Nugraha, 1999). Seperti terlihat pada hasil pengujian, kadar abu tak larut pada penyamakan nabati menggunakan gambir memenuhi syarat SNI. 0253:2009 dimana batas persentase kadar abu maksimal 5\%.

\section{Kadar Zat Penyamak (Tanin) Terikat}

Rataan kadar zat penyamak pada kulit kambing, tertinggi terdapat pada perlakuan $\mathrm{E}$ dengan rataan $36,14 \%$ dan terendah terdapat pada pada perlakuan A dengan rataan $27,44 \%$ (Gambar 4). Hasil analisis keragaman menunjukkan bahwa perlakuan memberikan pengaruh terhadap kadar zat penyamak (tanin) terikat penyamakan dengan gambir pada kulit samak.

Hasil uji jarak berganda Duncan's menunjukkan bahwa rataan kadar zat penyamak (tanin) terikat penyamakan dengan gambir pada kulit kambing pada perlakuan A berbeda nyata dengan perlakuan B, C, D dan E. Tingginya kadar zat penyamak pada perlakuan $\mathrm{E}$ disebabkan oleh kadar air, kadar zat kulit mentah, kadar zat larut dalam air, dan kadar abu tak larut yang rendah pada perlakuan ini dan demikian juga sebaliknya kadar zat penyamak (tanin) terikat terendah terdapat pada perlakuan A. Menurut Novia (2009) kadar zat penyamak terikat merupakan bagian komponen yang tersisa dari pengurangan komponen air, minyak, zat larut dalam air, abu tak larut dan zat kulit mentah yang terdapat dalam kulit hasil samak. Berbeda nyatanya kadar zat penyamak pada kulit samak disebabkan oleh kandungan tanin gambir yang tinggi yang diberikan dengan konsentrasi yang berbeda pada setiap perlakuan, di mana gambir dapat menyamak dan berikatan dengan sesamanya kemudian mengendap di antara serabut-serabut kulit. Menurut Kasim (2010), kadar zat penyamak (tanin) terikat dipengaruhi oleh sifat dan kandungan zat penyamak yang digunakan. Peningkatan kadar zat penyamak (tanin) terikat disebabkan oleh zat penyamak (tanin) gambir merupakan bahan penyamak yang mudah berpenetrasi ke dalam kulit, tetapi tidak bersenyawa dengan baik.

Purnomo (1991) selama proses penyamakan berlangsung terjadi 2 tahap dalam reaksinya yaitu, tahap pertama terjadinya reaksi antara gugus hidroksil yang terdapat dalam zat penyamak nabati dengan kolagen, tahap kedua diikuti oleh reaksi ikatan dari molekul zat penyamak dengan molekul zat penyamak lainnya yang sama sampai seluruh ruang kosong yang terdapat di antara rantai kolagen terisi seluruhnya. Pada penelitian sebelumnya, penyamakan nabati menggunakan daun/ranting gambir yang dipanaskan 


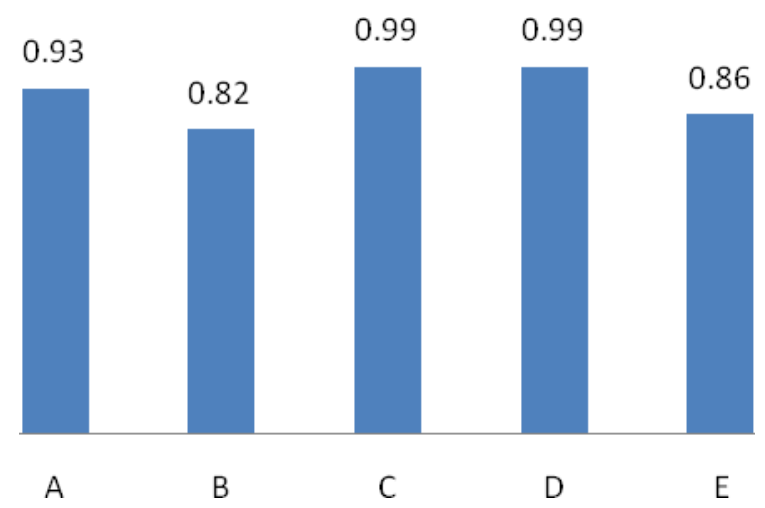

Gambar 3. Rataan Kadar Abu Tak Larut Hasil Penelitian (\%). A = penambahan gambir 15\%, B = $20 \%, \mathrm{C}=25 \%, \mathrm{D}=30 \%$ dan $\mathrm{E}=35 \%$

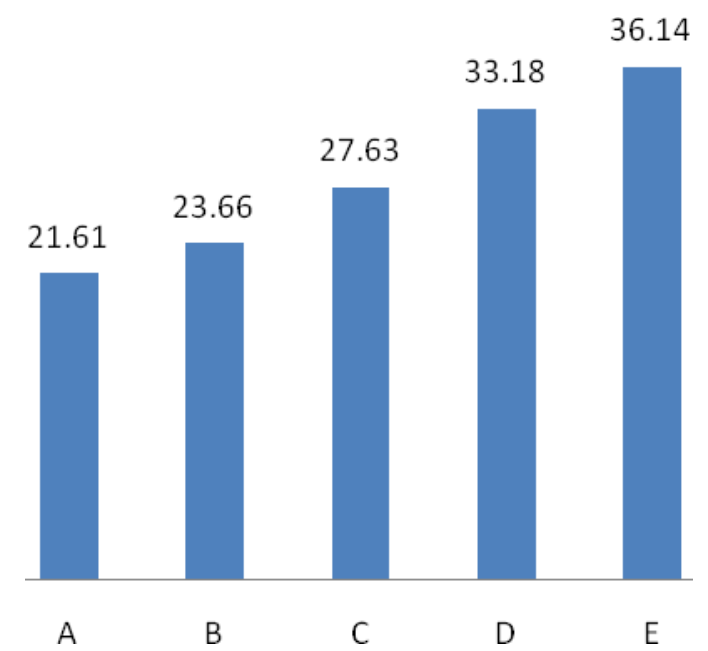

Gambar 4. Rataan Kadar Zat Penyamak (tannin) Terikat Hasil Penelitian (\%) $\mathrm{A}=$ penambahan gambir $15 \%, \mathrm{~B}=20 \%, \mathrm{C}=25 \%, \mathrm{D}=30 \%$ dan $\mathrm{E}=35 \%$

di atas api (didiang) sampai layu dan dikeringkan diperoleh rata-rata kadar zat penyamak (tanin) terikat 55,41\% (Novia, 2009).

Hasil kadar zat penyamak (tanin) terikat pada penelitian memenuhi mutu SNI. 060994-1989 dimana batas minimal 1,5\%.

\section{Derajat Penyamakan}

Rataan derajat penyamakan dengan gambir pada kulit kambing tertinggi terdapat pada perlakuan E dengan rataan 108,88\% dan terendah terdapat pada pada perlakuan A dengan rataan 48,58\% (Gambar 5). Hasil analisis keragaman menunjukkan bahwa perlakuan memberikan pengaruh terhadap kadar zat penyamak (tanin) terikat penyamakan dengan gambir pada kulit samak. Hasil uji jarak berganda Duncan's menunjukkan, bahwa rataan derajat penyamakan kulit samak dengan gambir pada perlakuan A. memberikan pengaruh berbeda nyata dengan perlakuan $\mathrm{B}$ dan $\mathrm{C}, \mathrm{D}$ dan E. Rendahnya derajat penyamakan pada perlakuan A karena pemberian konsentrasi gambir yang juga masih rendah, mengakibatkan tanin terikat yang masih rendah dan kadar zat kulit mentah yang masih tinggi sehingga mengakibatkan derajat penyamakan lebih rendah di bandingkan dengan perlakuan lainnya. Menurut Ibrahim dkk. (2005) larutan zat penyamak yang encer akan memiliki molekul zat penyamak yang kecil, daya ikat kecil, penetrasi cepat dan merata. Menurut Novia (2009), 
Derajat penyamakan (tingkat kemasakan kulit tersamak) merupakan jumlah zat penyamak (tannin) yang dapat terikat pada kulit dibandingkan dengan kadar protein (zat kulit mentah) dari kulit hasil samak dengan gambir. Hal ini menunjukkan seberapa besarnya kulit yang dapat disamak tergantung pada komponen kimia yang terdapat dalam kulit, hasil lengkap dari komponen kimia kulit dari masing-masing perlakuan.

Derajat penyamakan tertinggi terdapat pada perlakuan E. Tingginya derajat penyamakan pada perlakuan E seiring dengan peningkatan konsentrasi penambahan gambir, di mana semakin tinggi penambahan konsentrasi gambir yang diberikan akan menghasilkan derajat penyamakan yang lebih tinggi. Sesuai dengan Akademi Teknologi Kulit (1985) dalam Nugraha (1999) menyatakan, jumlah tannin yang terikat pada kulit dipengaruhi oleh banyaknya tanin yang dapat terdifusi kedalam jaringan kulit. Menurut Ibrahim dkk. (2005) konsentrasi bahan penyamak yang tinggi diluar kulit dapat meningkatkan difusi bahan penyamak. Ditambahkan Sharphouse (1978) dalam Nugraha (1999) untuk mempercepat difusi dan penetrasi bahan penyamak yang kadar penyamaknya tinggi dapat dibantu dengan gerakan mekanis. Oleh sebab itu semakin tinggi konsentrasi bahan penyamak dapat meningkatkan jumlah tanin terikat dan menurunkan kadar zat kulit mentahnya, sehingga diperoleh derajat penyamakan yang lebih tinggi.

Standar Nasional Indonesia (SNI) 060994-1989 menyatakan, jika derajat penyamakan terlalu tinggi menandakan bahwa bahan penyamaknya tinggi dan menyebabkan kulit masak sempurna serta baik fisiknya, sedangkan terlalu rendah menandakan kulit belum masak. Pada penelitian sebelumnya penyamakan nabati menggunakan gambir dengan konsentrasi $4 \%$ didapatkan derajat penyamakan $36,80 \%$ dan penyamakan nabati menggunakan limbah gambir dengan konsentrasi $4 \%$ didapatkan derajat penyamakan 21,65\% (Gustriyeni, dkk. 2009). Penyamakan nabati menggunakan kulit kayu akasia dengan konsentrasi $6 \%$ diperoleh derajat penyamakan $49,66 \%$ (Nugraha, 1999). Derajat penyamakan pada perlakuan A, B, C, D dan E memenuhi standar menurut SNI. 06-0994-1989, di mana batas minimal derajat penyamakan menurut SNI. 06-0994-1989 minimal 25\%.

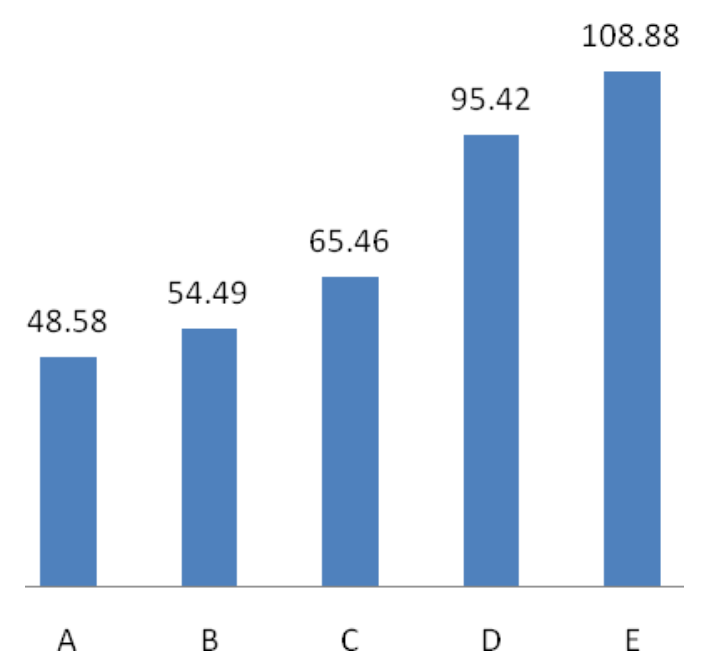

Gambar 5. Rataan Derajat Penyamakan Hasil Penelitian (\%) A = penambahan gambir 15\%, $\mathrm{B}=20 \%, \mathrm{C}=25 \%, \mathrm{D}=30 \%$ dan $\mathrm{E}=35 \%$

\section{KESIMPULAN}

Berdasarkan hasil penelitian menunjukkan pengaruh yang berbeda nyata $(\mathrm{P}<0,05)$ terhadap penurunan kadar air, kadar zat kulit mentah, kadar zat larut dalam air dan peningkatan derajat penyamakan dan berbeda tidak nyata $(\mathrm{P}>0,05)$ terhadap peningkatan kadar minyak, penurunan kadar abu dan peningkatan kadar zat penyamak (tanin) terikat. Kesimpulan dari penelitian ini adalah penambahan 25\% gambir merupakan persentase terbaik, dengan kadar air 17,06 $\pm 0,15 \%$, kadar lemak/minyak $7,69 \pm 1,24 \%$, kadar zat larut dalam air 4,16 $\pm 0,99 \%$, kadar zat kulit mentah $42,47 \pm 6,39 \%$, kadar abu tak larut 0,99 $\pm 0,03 \%$, kadar zat penyamak (tanin) terikat 27,63 $\pm 2,75 \%$ dan derajat penyamakan $65,46 \%$, di mana seluruh pengujian memenuhi standar mutu SNI. 06-0994-1989 dan SNI. 0253:2009.

\section{DAFTAR PUSTAKA}

Balai Besar Kulit, Karet dan Plastik Yogyakarta. 2010. Prosedur 
Penyamakan Nabati. Laboratorium Pengujian dan Kalibrasi. Yogyakarta.

Badan Pusat Statistik. 2010. Pemerintah Provinsi Sumatera Barat. Badan Perencanaan Pembangunan Daerah. Pemerintah Provinsi Sumatera Barat.

Badan Standarisasi Nasional. 1989. Standar Nasional Indonesia Kulit Lapis Domba/Kambing Samak Kombinasi (Khrom dan Nabati) No. 06-04631989. www.bsn.go.id. Diakses 22 November 2010 jam 20.00.

Badan Standarisasi Nasional. 2009. Kulit Bagian Atas Alas Kaki-Kulit Kambing. SNI No. 0253-2009.

Gustriyeni, Syafrudin, Marjali dan Yurnita. 2009. Perbedaaan Daya Samak dari Bahan Penyamak (Cube Black Limbah Gambir) terhadap Mutu dan Tekno Ekonomi Kulit. Balai Riset dan Standarisasi Industri Sumatera Barat. Padang.

Ibrahim, L., Juliyarsi, I dan Melya, S. 2005. Ilmu dan Teknologi Pengolahan Kulit. Fakultas Peternakan Universitas Andalas. Padang.

Kasim, A. 2011. Proses Produksi dan Industri Hilir Gambir. Universitas Andalas Press. Jakarta

Novia, D.2009. Pengaruh perlakuan awal daun /ranting tanaman gambir (Uncaria gambir Roxb) terhadap kadar tanin ekstrak yang dihasilkan dan kemampuan penyamakannya pada kulit kambing
Jurnal Peternakan 6(1) : 22-28.

Nugraha, G. 1999. Pemanfaatan Tanin dari Kulit Kayu Akasia (accacia mangium wild) Sebagai Bahan Penyamak Nabati. Teknologi Pertanian. Institut Pertanian Bogor.

Nurwanto dan A. S. Djarijah.1997. Mikrobiologi Pangan - Nabati. Kanisius, Yogyakarta.

Nurwanto dan Mulyani. 2003. Buku Ajar Dasar Teknologi Hasil Ternak. Universitas diponegoro. Semarang.

Purnomo. 1991. Penyamakan Kulit Reptil. Akademi Penyamakan Kulit. Yogyakarta.

Standar Nasional Indonesia. 1989. SNI. 060994-1989. Cara Uji Derajat Penyamakan (DP) Kulit samak. Dewan Standarisasi Nasional.

Sumarni, S. 2005. Petunjuk Praktikum Teknik Pembuatan Bahan Penyamak. Yogyakarta: ATK.

Sumarni, S. 2009. Laporan Resmi pengujian kimiawi kulit hasil samak khrom dan kulit hasil samak ekstrak akasia.www.scribd.com/doc/29548638 I Penyamakan. Diakses 1 desember 2010 jam 16.00.

Wahyuningsih, P. 2007. Persentase Penggunaan Bahan Samak Nabati pada Kulit Kelinci Samak Berbulu Ditinjau dari Daya Serap Air dan Organoleptik (Kekuatan, Kerataan, Kilauan Bulu). Universitas Brawijaya. Malang. 